\title{
THE BRYOPHYTE FLORA OF THE ERDŐTELEK ARBORETUM IN HUNGARY
}

\author{
Péter Szúcs* \& Gabriella Fintha \\ Eszterházy Károly University, Institute of Biology, Department of Botany and Plant \\ Physiology, H-3300 Eger, Leányka str. 6, Hungary; \\ *E-mail: szucs.peter@uni-eszterhazy.hu
}

\begin{abstract}
According to the present investigations 54 bryophyte species were collected in the Arboretum of Erdötelek, including 3 liverworts and 51 mosses. Most of this species are common in Hungary, one of them is vulnerable (Orthotrichum patens) and three species are listed as near threatened in the Hungarian Red Data List: Brachythecium glareosum, Cirriphyllum piliferum and Orthotrichum obtusifolium. In the recent paper a comparison of the number of bryophytes recorded in Hungarian botanical gardens and arboretums is presented.
\end{abstract}

Keywords: bryophyte diversity, NE-Hungary, comparison, red-list status, size of territories

\section{INTRODUCTION}

There are only a few publications on the bryophyte flora of the arboretums and botanical gardens of central and eastern european countries, for example Czech Republic (Hradílek 2012; Soldán 1999; Wallnerová 2015) Slovakia (Godovičová 2017) Romania (Ştefureac and Lungu 1961; Plămadă 1963), Poland (Wolski et al. 2012) and Ukraine (Mamchur et al. 2018).

The first significant description of the bryophyte flora of the hungarian botanical gardens were from Vácrátót (Vajda 1954) and Szigliget (Vajda 1968). Since then several new investigations were published in succession on mostly unexplored botanical gardens, arboretums, and parks: Tata (Agostyán) (Szűcs 2009), Zirc (Galambos 1992, Szűcs 2013), Martonvásár (Nagy et al. 2016), Soroksár (Németh and Papp 2016), Eger (Szűcs et al. 2017), 
Gyöngyös (Mátraháza) (Szűcs et al. 2018), Budapest (Rigó et al. 2019) and Göd (Fintha et al. in press).

This paper introduces the bryophyte flora of the Arboretum of Erdötelek, based on the investigations conducted in 2016 and 2019. Results were also compared with the bryopyhte diversity of other Hungarian botanical gardens or arboretums.

\section{MATERIALS AND METHODS}

The nomenclature follows Söderström et al. (2016) for liverworts, Hill et al. (2006) for mosses. To establish the indicator and conservation status of taxa the Hungarian Red List was used (Papp et al. 2010). Site detail descriptions (in the Appendix) include data in the following order: habitats, GPS-coordinates, and date of collection. The designation of the quadrates according to the Central European Flora Mapping System were indicated in square brackets (Király et al. 2003). We used the Sørensen index (1948) for the comparison of the species composition of different localities. Collected specimens are deposited at the Cryptogamic Herbarium of the Department of Botany and Plant Physiology at the Eszterházy Károly University, Eger (EGR).

\section{Study area}

As a part of the Heves Plains (Hevesi sík) microregion, the present research area is located on the alluvium of the Laskó and Eger streams, at an altitude of 107-118 m. The area's topography has low lying ground, floodless, sligthly undulating plain surface. It's climate is moderately warm and dry with an avarege annual temperature of $10-10.2{ }^{\circ} \mathrm{C}$ and annual precipitation is approximately $520-560 \mathrm{~mm}$. The microregion, due to the low water flow, is typically a dry, water-scarce area with a mosaic like soil formation. In the study area the most characteristic are loess materials, covering river and swamp clay on which brown Chernozem forest soils developed. On the western part of the microregion the formerly sandy vegetation has disappeared, but near Erdőtelek, by the spring of Hanyi-rill, there is a remnant of an alder swamp (Dövényi 2010).

The arboretum of Erdötelek is located on the outskirts of the Great Plain (Alföld) in Heves County, which total area is 25.5 hectares, of which only 6 hectares can be visited by public. The 
garden was established and transformed by József Kovács from the castle park into a rich dendrological collection. His important merit was to create an arboretum rich in evergreens on one of the dry, warm and low rainfall areas of the Great Plain. After World War II, the garden was almost destroyed due to damage caused by incompetented workers. It was a declared as a nature reserve in 1950. Occasionally, the tree trunks and the soil surface are covered by Hedera helix. Currently, the arboretum is a unit belonging to the Eszterházy Károly University. Maintenance consists of seasonal and local lawn mowing and leaf litter collection. There is an intensive horticulture activity in its the north-western part.

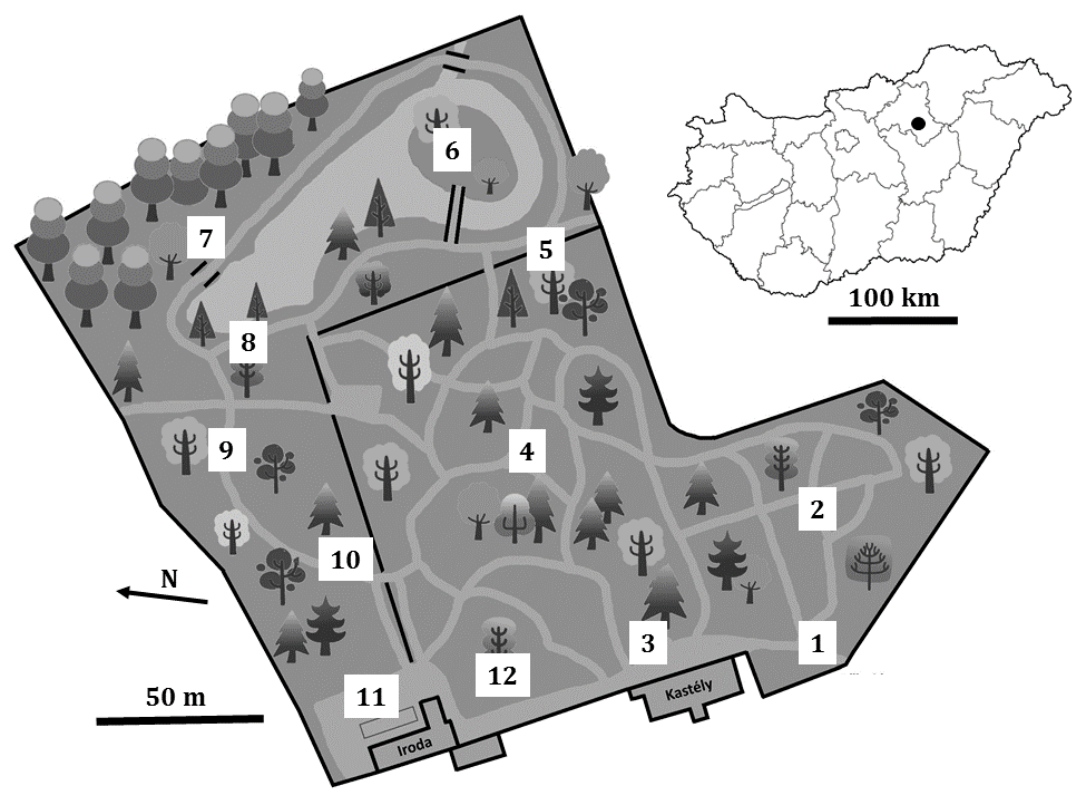

Figure 1. The collecting points in the Arboretum of Erdőtelek (map designed by Jana Táborská).

\section{RESULTS AND DISCUSSION}

Altogether 54 bryophyte species were identified from the Arboretum of Erdőtelek, including 3 liverworts and 51 mosses. Besides the common and frequent taxa, mosses which are still not threatened, but need attention (LC-att) according to the Hungarian Bryophyte Red List (Papp et al. 2010): Brachythecium albicans, 
Orthotrichum speciosum, Orthotrichum striatum, Tortula lanceola, Tortula papillosa and Tortula virescens.

Near threatened (NT) species were: Brachythecium glareosum, Cirriphyllum piliferum and Orthotrichum obtusifolium. Orthotrichum patens belong to vulnerable (VU) category according to the red list. Indicator bryophytes which by their mere presence denote the higher level of conservation value of the habitat, also occur in the arboretum are Cirriphyllum piliferum, Orthotrichum speciosum, Orthotrichum striatum, Tortula lanceola and Tortula papillosa.

Some common species of the most measured Hungarian botanic gardens and arboretums, includes: Amblystegium serpens, Barbula unguiculata, Brachythecium rutabulum, Bryum argenteum, Ceratodon purpureus, Hypnum cupressiforme, Leskea polycarpa, Orthotrichum anomalum, Orthotrichum diaphanum, Oxyrrhynchium hians, Radula complanata, Syntrichia ruralis and Tortula muralis occur also in the Arboretum of Erdőtelek.

The low number of liverworts in the territory is similar to the majority of other Hungarian botanic gardens, arboretums and parks (Szűcs 2017).

Table 1 shows a comparison between the species composition of the Erdőtelek Arboretum with other previously bryologically explored man made habitats (Botanical Garden of Eger, Mátrai Sanatorium park, Balaton village) species in the region calculated by Sørensen index. The greatest similarity was found in the Botanical Garden of Eger (0.7), but not far behind the value of Balaton village (0.67). The biggest difference was found in comparison with the Mátrai Sanatorium park (0.53).

Table 1. Comparison the territory, the distcance of localities, the altitude, the number of taxa and calculated Sørensen index of other territories with Arborétum of Erdőtelek.

\begin{tabular}{cccccc}
\hline Name of locality & $\begin{array}{c}\text { territory } \\
\text { (hectare) }\end{array}$ & $\begin{array}{c}\text { distance } \\
\text { from Arb. of } \\
\text { Erdőtelek } \\
\text { (km) }\end{array}$ & $\begin{array}{c}\text { alt } \\
\text { (meter) }\end{array}$ & $\begin{array}{c}\text { number } \\
\text { of taxa }\end{array}$ & $\begin{array}{c}\text { Sørensen } \\
\text { index }\end{array}$ \\
\hline $\begin{array}{c}\text { Bot. garden of Eger } \\
\text { (Szúcs } \text { et al. 2017) }\end{array}$ & 1 & 25 & 230 & 46 & 0.7 \\
$\begin{array}{c}\text { Mátrai Sanatorium, } \\
\text { Mátraháza }\end{array}$ & 14 & 36 & $650-$ & 65 & 0.53 \\
$\begin{array}{c}\text { (Szúcs } \text { et al. 2018) } \\
\text { Balaton village }\end{array}$ & 82 & 45 & $290-$ & 61 & 0.67 \\
$\begin{array}{c}\text { (Zsólyom \& Szúcs } \\
\text { 2018) }\end{array}$ & & & 320 & & \\
\hline
\end{tabular}


Compared to the above mentioned gardens, the following taxa occur only in Erdőtelek: Anomodon viticulosus, Brachythecium albicans, Leptobryum pyriforme, Orthotrichum patens, Plagiomnium rostratum, Porella platyhylla, Pseudocrossidium hornschuchianum.

Figure 2 indicates the number of bryophytes identified in Hungarian botanical gardens, arboretums and parks compared to the size of these collection gardens.

It can be stated that most gardens have a larger area with higher species numbers. The arboretum of Erdőtelek, with its 6 hectares and 54 species, also reinforces this tendency and has almost the same value as the Huzella Garden in Göd (Fintha et al. in press).

The difference is remarkable compared to Soroksár and Martonvásár. The different value of Tata (Agostyán) is also due to the fact that the complete bryophyte flora of the arboretum has not been investigated yet (Szücs 2009).

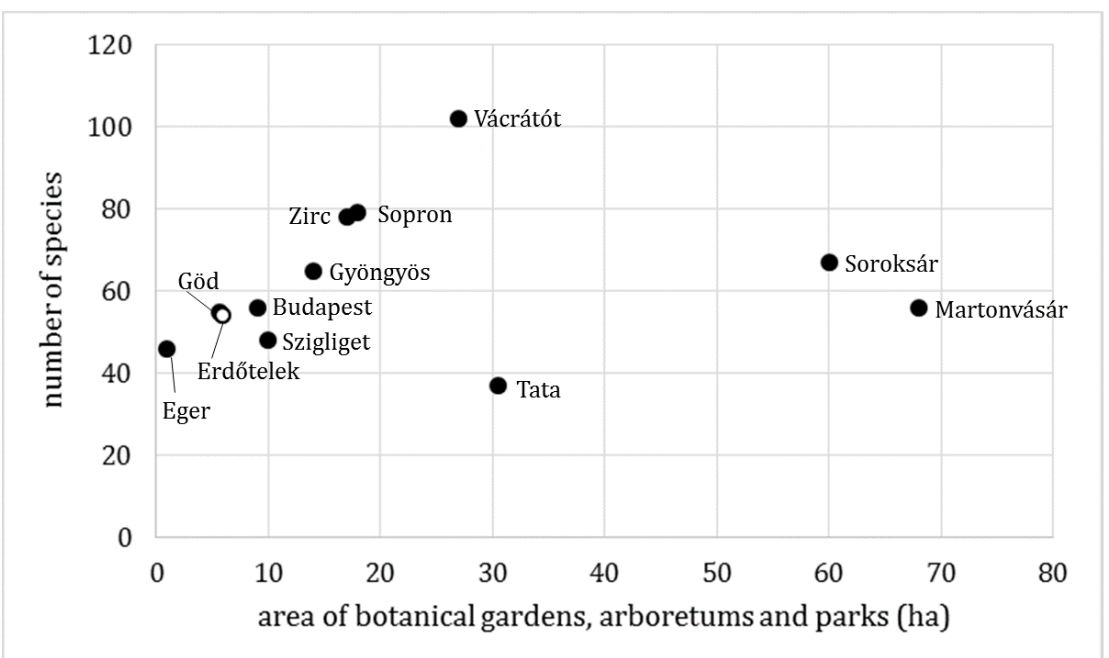

Figure 2. The number bryophytes recorded in Hungarian botanical gardens, arboretums and parks, in comparison to their sizes.

The data were obtained from the following sources: Tata (Agostyán) (Szűcs 2009), Budapest (Rigó et al. 2019), Eger, botanical garden (Szű́cs et al. 2017), Erdőtelek (present work), Göd (Fintha et al. in press), Gyöngyös (Mátraháza) (Szűcs et al. 2018), Martonvásár (Nagy et al. 2016), Sopron (Szűcs 2017), Soroksár (Németh and Papp 2016), Szigliget (Vajda 1968), Vácrátót (Vajda 1954), Zirc (Galambos 1992, Szűcs 2013). 


\section{List of species}

Numbers refer to sites (Figure 1.) listed in Appendix. The substrates given after a semicolon refer to all listed sites.

\section{Marchantiophyta}

Marchantia polymorpha L. - 11: soil in flower pots

Porella platyphylla (L.) Pfeiff. - 4: bark of old Fraxinus

Radula complanata (L.) Dumort. - 4: bark of old Fraxinus and Quercus robur; 7: bark of Alnus glutinosa; 10: bark of Magnolia obovata

\section{Bryophyta}

Amblystegium serpens (Hedw.) Schimp. - 1: decayed stump, tar paper; bark of Castanea sativa and Padus cerasus; 2: plaster; 4: bark of old Fraxinus, Acer cappadocicum, Aesculus hippocastanum, Berberis vulgaris; Fraxinus excelsior, Tilia miranda, Tilia platyphyllos, and Malus halliana; 5: tree base of Betula pendula; 8: bark of Liriodendron tulipifera

Anomodon viticulosus (Hedw.) Hook. \& Taylor - 4: bark of not identified tree; 8: bark of Liriodendron tulipifera

Barbula unguiculata Hedw. - 2, 10, 12: soil; 11: soil in flower pots

Brachytheciastrum velutinum (Hedw.) Ignatov \& Huttunen - 4: bark of Quercus robur; 5: soil

Brachythecium albicans (Hedw.) Schimp. - 5: tree base of Betula pendula

Brachythecium rutabulum (Hedw.) Schimp. 1, 4, 5: soil; 8: bark of Liriodendron tulipifera

Brachythecium glareosum (Bruch ex Spruce) Schimp. - 6: concrete

Bryum argenteum Hedw. - 12: disturbed and bare soil

Bryum caespiticium Hedw. - 11: soil in flower pots; 12: disturbed and bare soil

Bryum moravicum Podp. - 1: bark of Castanea sativa, tar paper, bark of old Quercus robur; 4: bark of Quercus robur, Acer negundo, and Fagus sylvatica; 8: bark of Liriodendron tulipifera

Calliergonella cuspidata (Hedw.) Loeske - 1, 2, 3, 4, 5, 10: soil

Campyliadelphus chrysophyllus (Brid.) R.S.Chopra - 11: soil in flower pots 
Ceratodon purpureus (Hedw.) Brid. -11: soil in flower pots Cirriphyllum piliferum (Hedw.) Grout - 1, 2, 3, 4, 5, 10: soil Cirriphyllum crassinervinum (Taylor) Loeske \& M.Fleisch. - 4: bark of Prunus; 12: soil

Fissidens taxifolius Hedw. - 4, 5: shaded soil

Funaria hygrometrica Hedw. - 11: soil in flower pots; 12: disturbed soil

Grimmia pulvinata (Hedw.) Sm. - 1: artifical rock, bark of Padus cerasus

Homalothecium lutescens (Hedw.) H.Rob. - 1, 4: soil, bark of Prunus

Homalothecium philippeanum (Spruce) Schimp. - 5: tree base of Betula pendula

Hypnum cupressiforme Hedw. - 1: bark of Castanea sativa, Padus cerasus and Quercus robur; 4: bark of Prunus serrulata, Celtis occidentalis, Crataegus oxyacantha, Acer cappadocicum, Acer negundo, Aesculus hippocastanum, Berberis vulgaris; Fraxinus excelsior, Quercus robur, Tilia miranda, Tilia platyphyllos, and Malus halliana; 7: bark of Alnus glutinosa; 10: bark of Hibiscus syriacus; 12: bark of Acer pseudoplatanus

Isothecium alopecuroides (Lam. ex Dubois) Isov. - 4: tree base of Quercus robur

Leptobryum pyriforme (Hedw.) Wilson - 12: disturbed soil

Leptodictyum riparium (Hedw.) Warnst. - 10: tree base of Magnolia obovata

Leskea polycarpa Hedw. - 1: decayed stump; on bark of Castanea sativa and old Quercus robur, and Padus cerasus; 3, 12: bark of Acer pseudoplatanus; 4: bark of Celtis occidentalis, Acer cappadocicum, Acer negundo, Aesculus hippocastanum, Berberis vulgaris, Fagus sylvatica, Fraxinus excelsior, Lonicera maackii, Tilia miranda, Tilia platyphyllos, and Malus halliana; 8: bark of Liriodendron tulipifera; 10: bark of Hibiscus syriacus

Orthotrichum affine Schrad. ex Brid. - 1: bark of Berberis vulgaris; 5: bark of Morus alba; 10: bark of Hibiscus syriacus

Orthotrichum anomalum Hedw. - 1: tar paper; artifical rock

Orthotrichum diaphanum Schrad. ex Brid. - 4: bark of Lonicera maackii; 7: bark of Alnus glutinosa; 10: bark of Hibiscus syriacus

Orthotrichum obtusifolium Brid. - 1: bark of Padus cerasus and Berberis vulgaris; 4: bark of Lonicera maackii; 8: bark of Liriodendron tulipifera; 10: bark of Hibiscus syriacus 
Orthotrichum pallens Bruch ex Brid. - 5: bark of Morus alba

Orthotrichum patens Bruch ex Brid. - 5: bark of Morus alba; 10: bark of Magnolia obovata

Orthotrichum speciosum Nees - 4: bark of Prunus serrulata; 10: bark of Hibiscus syriacus

Orthotrichum stramineum Hornsch. ex Brid. - 1: bark of Padus cerasus

Orthotrichum striatum Hedw. - 5: bark of Morus alba

Oxyrrhynchium hians (Hedw.) Loeske - 1, 2, 3, 4, 6, 7, 9: soil

Phascum cuspidatum Hedw. - 9: bare soil; 12: disturbed soil

Physcomitrium pyriforme (Hedw.) Bruch \& Schimp. - 11: soil in flower pots

Plagiomnium cuspidatum (Hedw.) T.J.Kop. - 1: bark of old Quercus robur

Plagiomnium rostratum (Schrad.) T.J.Kop. - 12: bare soil

Plagiomnium undulatum (Hedw.) T.J.Kop. - 1, 2, 3, 4, 5, 10: wet soil

Pseudocrossidium hornschuchianum (Schultz) R.H.Zander - 10: soil with gravel

Pseudoscleropodium purum (Hedw.) M.Fleisch. - 1, 4, 8, 10: wet soil

Pylaisia polyantha (Hedw.) Schimp. - 1: bark of Padus cerasus; 4: bark of Prunus serrulata and Berberis vulgaris; 7: bark of Alnus glutinosa; 8: bark of Liriodendron tulipifera; 10: bark of Hibiscus syriacus

Rhytidiadelpus squarrosus (Hedw.) Warnst. - 3, 8, 9, 10: wet soil

Schistidium crassipilum H.H.Blom 1: artifical rock

Syntrichia ruralis (Hedw.) F.Weber \& D.Mohr - 1: bark of Padus cerasus; 4: bark of Berberis vulgaris; 11: artifical rock

Syntrichia papillosa (Wilson) Jur. - 1: bark of old Quercus robur and Padus cerasus; 4: bark of Celtis occidentalis and Lonicera maackii 12: bark of Acer pseudoplatanus

Syntrichia virescens (De Not.) Ochyra - 1: tar paper, bark of old Quercus robur and Padus cerasus; 4: bark of Celtis occidentalis, Fraxinus excelsior, and Lonicera maackii; 7: bark of Alnus glutinosa; 12: bark of Acer pseudoplatanus

Thuidium assimile (Mitt.) A.Jaeger - 3, 4, 5, 9, 10: soil

Tortula lanceola R.H.Zander - 12: disturbed and bare soil

Tortula muralis Hedw. - 1: artifical rock; 5: plaster and brick; 7: concrete 
Acknowledgement - The authors would like to express their gratitude to Andrea Sass-Gyarmati and Tamás Pócs for their useful comments. The first author's research was supported by the grant EFOP-3.6.1-16-2016-00001 ("Complex improvement of research capacities and services at Eszterházy Károly University"). Special thanks to András Schmotzer and Jana Táborská for their help in literatures and preparing the map, and Gergely Baranyi for his help in field works. The authors are grateful to Tamás Zöllei (director of Arborétum of Erdőtelek) for permission the sample collection possible.

\section{REFERENCES}

DövÉNYI, Z. (ed.) (2010). Magyarország kistájainak katasztere. MTA Földrajztudományi Kutatóintézet, Budapest, 824 pp.

FinThA, G., SzŰCs, P. \& ERZBERGER, P. (in press). A gödi Huzella Kert mohaflórája. (The bryophyte flora of Huzella garden in Göd town (Pest county, Hungary)). Botanikai Közlemények 107.

Galambos, I. (1992). A Zirci Arborétum mohaflórája. Folia Musei historico-naturalis Bakonyiensis 11: 29-35.

Godovičové, K. (2017). Bryophytes of the Botanical Garden of the Comenius University in Bratislava. Acta Botanica Universitatis Comenianae 52: 29-34.

Hill, M.O., Bell, N., Bruggeman-Nannaenga, M.A., Brugues, M., Cano, M.J., Enroth, J., Flatberg, K.I., Frahm, J.-P., Gallego, M.T., Garilleti, R., Guerra, J., Hedenäs, L., Holyoak, D.T., Hyvönen, J., Ignatov, M.S., Lara, F., Mazimpaka, V., Munoz, J. \& SöDERSTRÖM, L. (2006). An annotated checklist of the mosses of Europe and Macaronesia. Journal of Bryology 28: 198-267. https://doi.org/10.1179/174328206X119998

HradíleK, Z. (2012). Mechorosty: mechorosty Botanické zahrady Př́rodovědecké fakulty Univerzity Palackého v Olomouci. 1. vyd. Olomouc: Univerzita Palackého v Olomouci.

Király, G., Balogh, L., Barina, Z., Bartha, D., BAuer, N., Bodonczi, L., DAncza, I., FARKaS, S., Galambos, I., Gulyás, G., Molnár, V. A., NAgy, J., Pifkó, D., Schmotzer, A., Somlyai, L., Szmorad, F., VidéKI, R., VojtKó, A., \& Zólyomi, Sz. (2003). A magyarországi flóratérképezés módszertani alapjai. Flora Pannonica 1: 3-20.

Mamchur, Z., DraCh, Y. \& DANYLKIV, I. (2018). Bryoflora of the "Pohulyanka" forest park (Lviv city) I. Changes in taxonomic composition under anthropogenic transformation. Studia Biologica 12(1): 99-112. https://doi.org/10.30970/sbi.1201.542

NAGY, Z., MAJLÁTH, I., MolnÁR, M. \& ERZBERGER, P. (2016). A Martonvásári Kastélypark mohaflórája. (Bryofloristical study in the Brunszvik manor park in Martonvásár, Hungary). Kitaibelia 21(2): 198-206.

https://doi.org/10.17542/kit.21.198

NÉmeth, Cs. \& PAPP, B. (2016). Mohák a Soroksári Botanikus Kertben. In: HöHN, M., PAPP, V. (szerk): Biodiverzitás a Soroksári Botanikus Kertben. Magyar Biodiverzitás-kutató Társaság and SZIE Kertészettudományi Kar, Soroksári Botanikus Kert, Budapest, pp. 111-149.

PAPP, B., ERZBerger, P., Ódor, P, Hock, Zs., SzövÉnyi, P., Szurdoki, E. \& Tóth, Z. (2010). Updated checklist and Red List of Hungarian Bryophytes. Studia Botanica Hungarica 41: 31-59. 
PlăMADĂ, E. (1963). Briofite din gradina Bontanica din Clij. Studii si Cercetăry de Biologie 14(2): 177-194.

Rigó, A., Kovács, A. \& NÉmeth, Cs. (2019). A Budai Arborétum mohaflórája. (Bryophyte flora of the Buda Arboretum (Budapest, Hungary)). Botanikai Közlemények 106(2): 217-235. https://doi.org/10.17716/BotKozlem.2019.106.2.217

Soldán, Z. (1999). The bryophyte flora of the Charles University Botanical Garden in Prague. Novitates Botanicae ex Universitate Carolinae 13: 27-33.

SøRENSEN, T. (1948). A method of establishing groups of equal amplitude in plant sociology based on similarity of species content. Kongelige Dansk e Videnskabernes Selskab. Biologiske Skrifter 4: 1-34.

SöDerström, L., Hagborg, A., Von Konrat, M., Bartholomew-Began, S., Bell, D., Briscoe, L., Brown, E., Cargill, D.C., Costa, D.P., Crandall-Stotler, B.J., Cooper, E.D., Dauphin, G., Engel, J.J., FeldberG, K., Glenny, D., Gradstein, S.R., He, X., Heinrichs, J., Hentschel, J., Ilkiu-Borges, A.L., Katagiri, T., Konstantinova, N.A., Larraín, J., Long, D.G., Nebel, M., Pócs, T., Puche, F., Reiner-Drehwald, E., Renner, M.A.M., Sass-Gyarmati, A., SchäFer-Verwimp, A., Moragues, J.G.S., Stotler, R.E., SukKharaK, P., Thiers, B.M., URibe, J., VÁŇA, J., Villarreal, J.C., Wigginton, M., ZhanG, L. \& ZhU, R.-L. (2016). World checklist of hornworts and liverworts. PhytoKeys 59: 1828. https://doi.org/10.3897/phytokeys.59.6261

ŞTEFurEAC, T.I. \& LunGu, L. (1961). Bryofite din Gradina Botanica din Bukaresti. Acta Botanica Horti Bucarestiensis 273-280.

Szúcs, P. (2009). Mohaadatok az Agostyáni Arborétumból. (Data to the bryophyte flora of Agostyán Arboreum, Tata, NW Hungary). Komárom-Esztergom Megyei Múzeumok Közleményei 15: 159-164.

SzÛ́cs, P. (2013). Kiegészítések a Zirci Arborétum mohaflórájához. (Contribution to the bryophyte flora of Arboretum Zirc (NW-Hungary)). Folia Musei HistoricoNaturalis Bakonyiensis 30: 47-54.

SzÚcS, P. (2017). Bryophyte flora of the Botanic Garden of the University of Sopron (W Hungary). Studia botanica hungarica 48: 77-88. https://doi.org/10.17110/StudBot.2017.48.1.77

SZÚcs, P., TÁborská, J., BARANYI, G. \& PÉNZESnÉ-KónYa, E. (2017). Short-term changes in the bryophyte int he botanical garden of Eszterházy Károly University (Eger, NE Hungary). Acta Biologica Plantarium Argiensis 5(2): 52-60. https://doi.org/10.21406/abpa.2017.5.2.52

SzÚCS, P., Baranyi, G. \& Fintha, G. (2018). The Bryophyte flora of the park of Mátrai Gyógyintézet Sanatorium (NE Hungary). Acta Biologica Plantarum Agriensis 6: 123-132. https://doi.org/10.21406/abpa.2018.6.123

VAJDA, L. (1954). A Vácrátóti Botanikai Kutató Intézet Természetvédelmi Parkjának mohái. (Die Moose im Naturschutzparke des Botanischen Forschungsinstitutes von Vácrátót.) Botanikai Közlemények 45: 63-66.

VAJDA, L. (1968). A Szigligeti Arborétum mohái (The bryophytes of Arboretum Szigliget). A Veszprém Megyei Múzeumok Közleményei 7: 237-239.

Wallnerová, D. (2015). Mechorosty v botanické zahradě Př́rodovědecké fakulty Masarykovy univerzity v Brne. Stredoškolská odborná činnost', Brno.

Wolski, G.J., StefaniaK, A. \& KowalkiewicZ, B. (2012). Bryophytes of the experimental and teaching garden of the faculty of biology and environmental 
protection, University of Łódź (Poland). Ukrainian Botanical Journal 69(4): 519-529.

ZsóLYom, D. \& SzÚCS, P. (2018). Balaton település (Heves megye) mohaflórája. (The bryophyte flora of Balaton village (Heves county, Hungary)). Botanikai Közlemények 105(2): 231-242.

https://doi.org/10.17716/BotKozlem.2018.105.2.231

\section{APPENDIX}

\section{Site details}

Collection of the specimens was carried out in Heves County, in the territory of the local administrative unit of Erdőtelek village. Each collection point belongs to 8387.2 quadrant.

1. dendrological collection, woody vegetation, roadside, pagoda, stone fence; $\mathrm{N}^{\circ} 47.688352, \mathrm{E}^{\circ} 20.312575$ (06.07.2016, 01.05.2019, 16.11.2019)

2. dendrological collection, woody vegetation, roadside, bare soil surface; $\mathrm{N}^{\circ} 47.688446, \mathrm{E}^{\circ} 20.313391(06.07 .2016,01.05 .2019,16.11 .2019)$

3. mown lawn, bare soil surface, abandoned building, $\mathrm{N}^{\circ} 47.688792, \mathrm{E}^{\circ} 20.312468$ (06.07.2016, 01.05.2019, 16.11.2019)

4. dendrological collection, woody vegetation, roadside, bare and shaded soil surface, mown lawn $\mathrm{N}^{\circ} 47.689319$, E²0.312998 (06.07.2016, 01.05.2019, 16.11.2019)

5. dendrological collection, woody vegetation, roadside, lakeshore, mown lawn, bare soil; $\mathrm{N}^{\circ} 47.689316, \mathrm{E}^{\circ} 20.314538(06.07 .2016,01.05 .2019,16.11 .2019)$

6. island, mown lawn, concrete; $\mathrm{N}^{\circ} 47.689590, \mathrm{E}^{\circ} 20.315104 \quad$ (06.07.2016, 01.05.2019, 16.11.2019)

7. Alnus glutinosa vegetation, stone bridge, lakeshore, roadside; $\mathrm{N}^{\circ} 47.690168$, $\mathrm{E}^{\circ} 20.314798$ (01.05.2019, P., 16.11.2019)

8. dendrological collection, woody vegetation, roadside, mown lawn; $\mathrm{N}^{\circ} 47.689945$, $\mathrm{E}^{\circ} 20.314516$ (06.07.2016, 01.05.2019, 16.11.2019)

9. dendrological collection, woody vegetation, roadside, mown lawn; $\mathrm{N}^{\circ} 47.689994$, $\mathrm{E}^{\circ} 20.313759$ (06.07.2016, 01.05.2019, 16.11.2019)

10. dendrological collection, woody vegetation, roadside, mown lawn; $\mathrm{N}^{\circ} 47.689957, \mathrm{E}^{\circ} 20.313290(06.07 .2016,01.05 .2019,16.11 .2019)$

11. horticulture, outbuildings, roadside; $\mathrm{N}^{\circ} 47.689807, \mathrm{E}^{\circ} 20.312183$ (01.05.2019, 16.11.2019)

12. horticulture, foil tent, woody vegetation, roadside, bare soil; $\mathrm{N}^{\circ} 47.689599$, $\mathrm{E}^{\circ} 20.312385$ (06.07.2016, 01.05.2019, 16.11.2019)

(submitted: 11.12.2019, accepted: 30.12.2019) 